\title{
PENGEMBANGAN PERANGKAT PEMBELAJARAN SAINS BERORIENTASI GUIDED DISCOVERY UNTUK MENGAJARKAN KEMAMPUAN BERPIKIR KREATIF DAN PENGUASAAN KONSEP
}

\author{
Tilal Afian ${ }^{1)}$ \\ Muslimin Ibrahim ${ }^{2)}$ \\ Rudiana Agustini ${ }^{2)}$ \\ ${ }^{1)}$ Mahasiswa Prodi Pendidikan Sains Program Pascasarjana Unesa \\ ${ }^{2)}$ Dosen Prodi Pendidikan Sains Program Pascasarjana Unesa \\ e-mail: tilal.afian@gmail.com
}

\begin{abstract}
This study is aimed at teaching the ability of creative thinking and the comprehension of concept for students by developing science learning kit which mainly refer to guided discovery method. This is development research. The learning kit being validated by experts are syllabus, lesson plan, student work sheet, student learning book, mastering concept questions, and creative thingking questions. The learning kit was tested to 35 Grade X students in SMAN 1 Manyar. The design of study applies one group pretest-posttest with descriptive qualitative data analysis technique. The test results of learning kit are: the feasibility of lesson plan for three meetings has very good category; mastering concept ability, assessed from the mastery of indicators, reached $80 \%$ is in accomplished category; individual mastery reached $70 \%$ is in accomplished category. Students' creative thinking ability before the learning was $28,6 \%$. It is categorized as less creative. After students having guided discovery in learning, students achieved $84,86 \%$ or creative category and the average of students' conceptual comprehension is $N$-Gain > 0,70. This shows a high comprehension of concept on environment changes and waste recycling topic. Based on the test results, it is concluded that science learning kit developed is feasible, practical, and effective to teach creative thinking ability for students.
\end{abstract}

Key words: Guided Discovery Method, Creative Thinking Ability, the Mastery of Concept

\begin{abstract}
Abstrak: Penelitian ini bertujuan untuk mengajarkan kemampuan berpikir kreatif dan penguasaan konsep siswa yang dilakukan dengan cara mengembangkan perangkat pembelajaran sains dengan metode guided discovery. Jenis penelitian ini adalah pengembangan.Perangkat pembelajaran yang dikembangkan meliputi silabus, RPP, LKS, buku ajar siswa, soal penguasaan konsep, dan soal berpikir kreatif yang divalidasi oleh pakar.Ujicoba perangkat dilakukan pada 35 siswa kelas X SMAN 1 Manyar. Desain Penelitian menggunakan one group pretest-postest. Parameter yang diukur meliputi keterlaksanaan RPP, tes hasil belajar, kemampuan berpikir kreatif dan penguasaan konsep.Teknik analisis data deskriptif kualitatif.Hasil uji coba perangkat pembelajaran menunjukkan: keterlaksanaan RPP selama tiga kali pertemuan berkategori sangat baik, kemampuan penguasaan konsep dilihat dari ketuntasan indikator $\geq 80 \%$ dikategorikan tuntas, ketuntasan individu $\geq 75$ dikategorikan tuntas. Kemampuan berpikir kreatif siswa sebelum pembelajaran adalah $28,6 \%$ dengan kategori kurang kreatif dan rata-rata perolehan siswa setelah pembelajaran $84,86 \%$ dengan kategori kreatif, rata-rata kemampuan penguasaan konsep setelah mengikuti pelajaran $N$-Gain $>0,70$, ini menunjukkan penguasaaan konsep yang tinggi terhadap materi perubahan lingkungan dan daur ulang limbah. Berdasarkan hasil ujicoba, disimpulkan bahwa perangkat pembelajaran sains dengan metode guided discovery yang telah dikembangkan layak, praktis dan efektif untuk mengajarkan kemampuan berpikir kreatif siswa.
\end{abstract}

Kata-kata kunci:Metode Guided Discovery, Kemampuan Berpikir Kreatif, Penguasaan Konsep

\section{PENDAHULUAN}

Sains merupakan sekumpulan pengetahuan yang mengandung empat hal yaitu: produk, proses, sikap, dan teknologi (Carin, 1993). Produk merupakan hasil dari ilmu pengetahuan sedangkan proses merupakan langkahlangkah ilmiah atau metode ilmiah yang ditempuh seseorang untuk memperoleh pengetahuan. Dengan keterampilan proses, seseorang akan mampu belajar mandiri, mengembangkan diri sendiri, dan belajar sepanjang hayat (Ibrahim, 2010). Hal tersebut sejalan dengan peraturan pemerintah Nomor 32 Tahun 2013, proses pembelajaran pada satuan pendidikan diselenggarakan secara interaktif, inspiratif, menyenangkan, menantang, memotivasi peserta didik untuk berpartisipasi aktif, serta memberikan ruang yang cukup bagi prakarsa, kreativitas, dan kemandirian sesuai dengan bakat, minat, dan perkembangan fisik serta psikologis peserta didik.

Pembelajaran yang efektif dapat membuat siswa mencari, menemukan, dan melihat pokok masalah dan berusaha memecahkan masalah tersebut (Daryanto, 2009). Proses pembelajaran efektif dapat mengembangkan sikap, keterampilan, pengetahuan peserta didik yang berdimensi mental fisik dan sosial, dan memudahkan peserta didik belajar sesuatu yang bermanfaat (Suprijono, 2009). Besar kecilnya tingkat kemauan belajar peserta didik tergantung pada besar kecil motivasinya bila mereka tahu manfaat dari kegiatan belajarnya. Proses pembelajaran yang menyenangkan mampu memberikan hasil yang baik, karena sesuatu yang menyenangkan mendorong motivasi positif dan membentuk sikap positif (Daryanto dan Tasrial, 2012).

Pembelajaran yang dilakukan di sekolah masih dikatakan belum efektif. Hal ini berdasarkan hasil identifikasi di SMAN 1 Manyar kelas X Tahun Pelajaran 2013/2014. Pembelajaran yang digunakan sudah mengacu pada kurikulum 2013, namun hasil belajar yang didapatkan belum maksimal disebabkan beberapa faktor seperti metode mengajar yang digunakan tidak sesuai dengan materi pelajaran, akibatnya siswa kurang 
termotivasi dalam belajar. Sarana belajar seperti laboratorium kurang dapat dimanfaatkan, ketika dihadapkan dengan praktik secara langsung siswa merasa kesulitan.

Kemampuan berpikir dan penguasaan konsep menggunakan metode berbeda dapat memberikan pengalaman dan keterampilan baru bagi siswa. Keterampilan menerapkan pendekatan induktif dan deduktif, menerapkan pendekatan pemecahan masalah sangat penting dalam proses belajar mengajar dari berbagai aspek perencanaan kurikulum (Khasnis \& Aithal, 2011). Adanya kreatifitas pada seseorang mampu menunjukkan kemampuan diri dan memikirkan alternatif solusi atau tindakan yang tidak dilakukan oleh orang pada umumnya karena bukan sesuatu yang sudah biasa dilakukan dan tidak malu bertanya untuk mengetahui berbagai informasi tentang sesuatu yang dianggap menarik.

Keberhasilan proses dan hasil dalam kegiatan belajar mengajar tidak lepas dari peran guru yang selalu mengharapkan semua ilmu pengetahuan, kecakapan, dan keterampilan yang telah diajarkan dapat diterima, diingat, dan dikembangkan dengan baik secara kreatif oleh siswa. Kurikulum, dan penilaian,sangat berpengaruhdalam pembentukansikapsiswaterhadap ilmu pengetahuan, seperti kualitaspengajaran yangmereka alami.Pembelajaranyang melibatkanindividusecara aktifmenanggapi informasidan situasi dapat digunakansaat bekerjadengankelompok kecil atauseluruhkelas, dan dapatmembantu mencapaitujuanseperti memperkenalkanide-ide baruatau mendukungpeserta didik menggunakan kemampuanuntuk diri mereka sendiri (Diamond, 2006).

Salah satu permasalahan yang paling dekat dengan siswa adalah perubahan lingkungan yang paling banyak dibahas dalam kajianbiologi.Perubahan tersebut dapat berasal dari bahan pencemar yang ada di sekitar siswa atau yang dikenal sebagai limbah.Limbah yang ada di sekitar siswa terdapat beberapa jenis.Jenis-jenis limbah ini harus dikenal oleh siswa sehingga siswa mampu mengatasinya. Hal ini sesuai dengan kompetensi dasar biologi kelas $\mathrm{X}$ semester 2 yaitu siswa dapatmengidentifikasi perubahan lingkungan dan daur ulang limbah. Cara yang digunakan untuk mengajarkan bagaimana siswa mampu menganalisis perubahan lingkungan dan bagaimana mengatasinya, dapat di ajarkan melalui pembelajaran biologi yang berorientasi guided disecovery.

Pembelajaran penemuan terbimbing (guided discovery) merupakan model pembelajaran yang melatih dan membimbing siswa untuk belajar, memperoleh pengetahuan, dan membangun konsep-konsep yang mereka temukan untuk diri mereka sendiri (Carin, 1993).Guided discovery menekankanpentingnyakreativitasbelajardalam memfasilitasipencapaiankonseppada peserta didik.Siswa dilibatkan secara langsungdenganpraktekyang berpusat pada siswa (Udo \& Effiong, 2010).Peserta didik didorong untuk berpikir dan menganalisis sendiri sehingga dapat menemukan prinsip umum berdasarkan bahan atau data yang disediakan guru.

Guided discovery merupakan model yang sangat efektif karena memuat dua kriteria penting dalam pembelajaran aktif, yaitu membangun pengetahuan yang tepat untuk mempermudah pemahaman tentang informasi baru dan menyempurnakan informasi tersebut atas dasar yang dimiliki siswa atas dukungan guru, lingkungan atau dorongan yang kuat dalam dirinya sendiri (Saputro, 2012).Menguasai konsep yang baik, siswa memiliki kemampuan keterampilan yang baik pula.Keberhasilan siswa dalam memahami materi pelajaran, tergantung pada guru sebagai pembimbing yang harus bertindak sebagai motivator dan fasilitator yang baik(Munandar, 2009).

Berdasarkan uraian di atas maka peneliti melakukan penelitian dengan judul "Pengembangan Perangkat Pembelajaran Sains Berorientasi Guided Discovery Untuk Mengajarkan Kemampuan Berpikir Kreatif dan Penguasaan Konsep".

Tujuan umum dalam penelitian ini adalah mengembangkan perangkat pembelajaran sains yang valid, praktis, dan efektif untuk mengajarkan kemampuan berpikir kreatif dan penguasaan konsep

\section{METODE PENELITIAN}

Penelitian ini merupakan jenis penelitian pengembangan (developmental research), dalam penelitian ini mengembangkan beberapa perangkat pembelajaran berorientasiguided discovery. Adapun perangkat pembelajaran tersebut meliputi: Silabus, Rencana Pelaksanaan Pembelajaran (RPP), Lembar Kerja Siswa (LKS), Buku Ajar Siswa, Tes Penguasaan Konsep, dan Tes Berpikir Kreatif.

Penelitianini dilaksanakan pada semester 2 Tahun Pelajaran 2013/2014, kelas X dengan jumlah siswa 35 orang di SMAN 1 Manyar Kabupaten Gresik. Subjek penelitian ini adalah perangkat pembelajaran biologi berorientasi guided discovery.

Pembelajaran yang dilakukan pada penelitian ini adalah 35 siswa pada materi perubahan lingkungan dan daur ulang limbah. Rancangan yang digunakan yaitu One Group Pretest-Postest Design (Sugiyono, 2012) digambarkan dengan pola sebagai berikut:

\begin{tabular}{|ccc|}
\hline Uji Awal & Perlakuan & Uji akhir \\
$\mathrm{O}_{1}$ & $\mathrm{X}$ & $\mathrm{O}_{2}$ \\
\hline
\end{tabular}

$\mathrm{O}_{1}=$ Memberikan uji awal, untuk merekam penguasaan siswa sebelum diberikan perlakuan.

$\mathrm{X}=$ Memberikan perlakuan pada siswa, yaitu pembelajaran dengan menggunakanperangkat yang berorientasi guided discovery.

$\mathrm{O}_{2}=$ Memberikan uji akhir, untuk mengetahui hasil belajar siswa setelah diberikan perlakuan.

Perangkat pembelajaran yang dikembangkan meliputi silabus, RPP, lembar kegiatan siswa LKS, buku ajar siswa, tes penguasaan konsep dan tes berpikir kreatif siswa pada materi limbah dan daur ulang limbah. Tahap pengembangan meliputi empat tahap yaitu model 
pengembangan 4D (design, define, develop,dessiminate) diadaptasi menjadi Model 4P, yaitu pendefinisian, perancangan, pengembangan dan penyebaran (Ibrahim 2008)

Terdapat dua hal utama yang mempengaruhi kualitas data hasil penelitian yaitu kualitas intrumen penelitian yang berkenaan dengan validitas dan reliabilitas instrumen dan kualitas atau teknik pengumpulan data yang berkenaan dengan ketepatan cara-cara yang digunakan untuk mengumpulkan data (Sugiyono,2012). Untuk mendapatkan data penelitian, digunakan beberapa teknik pengumpulan data antara lain: obeservasi, pemberian tes, pemberian angket, dan validasi.

\section{Teknik Analisis Data}

Analisis hasil pengembangan perangkat pembelajaran dan hasil ujicoba perangkat pembelajaran fisika yang menggunakan model pembelajaran inkuiri terbimbing dalam penelitian ini adalah sebagai berikut:

1. Analisis Validitas Perangkat Pembelajaran

Analisis validasi data yang meliputi validasi perangkat dan penilaian dilakukan dengan merata-rata skor masing-masing komponen yang diperoleh dari validator

\begin{tabular}{|c|c|c|}
\hline Interval & Kategori & Keterangan \\
\hline $1,0 \leq \mathrm{SV} \leq 1,5$ & Tidak baik & $\begin{array}{l}\text { Belum dapat digunakan, } \\
\text { memerlukan konsultasi }\end{array}$ \\
\hline $1,6<\mathrm{SV} \leq 2,5$ & Kurang baik & $\begin{array}{l}\text { Dapat digunakan } \\
\text { dengan banyak revisi }\end{array}$ \\
\hline $2,6<\mathrm{SV} \leq 3,5$ & Baik & $\begin{array}{c}\text { Dapat digunakan } \\
\text { dengan sedikit revisi }\end{array}$ \\
\hline $3,6<\mathrm{S} \leq 4,0$ & Sangat baik & $\begin{array}{c}\text { Dapat digunakan, tanpa } \\
\text { revisi }\end{array}$ \\
\hline
\end{tabular}

2. Analisis Tes Penguasaan Konsep

a. Tes penguasaan konsep

Analisis tes penguasaan konsep dilakukan untuk mengetahui ketuntasan penguasaan konsep dan sensitivitas butir soal. Berdasarkan data hasil pretest dan postest, kemudian dianalisis secara deskriptif kuantitatif. Analisis dilakukan dengan langkah-langkah sebagai berikut:

1) Ketuntasan Indikator

Ketuntasan indikator dihitung dengan menggunakan rumus:

$K I=\frac{\sum \text { siswa yang mencapai indikator tertentu }}{\sum \text { siswa }} \times 100 \%$

Suatu indikator dikatakan tuntas apabila $\geq 80 \%$, siswa mencapai ketuntasan indikator.

2) Analisis ketuntasan individu

Standar yang digunakan untuk menentukan ketuntasan individu siswa dalam penelitian ini adalah apabila ketercapaian individu memenuhi Kriketria Ketuntasan Minimal (KKM) mata pelajaran biologi yang ditetapkan, yaitu $n \geq$
75.Adapun rumus ketuntasan hasil belajar adalah sebagai berikut:

$K I=\frac{\text { Jumlah Butir dengan Jawaban Benar }}{\text { Jumlah Seluruh Butir Soal }} \times 100 \%$

Indeks sensitivitas efektif terdapat antara 0,00 sampai 1,00. Gronlund (1985) menjelaskan sensitivitas butir soal pilihan ganda dihitung dengan rumus sebagai berikut:

$$
S=\frac{R a-R b}{T}
$$

\section{Keterangan:}

$\mathrm{S}=$ Sensitivitas butir soal

$\mathrm{Ra}=$ Banyak siswa yang menjawab benar pada tes akhir $\mathrm{Rb}=$ Banyak siswa yang menjawab benar pada tes awal

$\mathrm{T} \quad \mathrm{T}=$ Banyak siswa yang megikuti tes

\section{b. Analisis Tes Kemampuan Berpikir Kreatif}

Penilaian kreativitas siswa diperoleh dari tes kreativitas siswa.Masing-masing item tes dinilai dengan metode penskoran berdasarkan indikator yang telah ditetapkan. Dalam penelitian ini, siswa dikatakan kreatif apabila hasil perolehan skor tes kreativitas $\geq 61,2 \%$ (Khanafiyah, 2010). Peningkatan kreativitas diperoleh dengan menganalisis skor tes kreativitas siswa sebelum dan sesudah pembelajaran dengan metode guideddiscovery (Harini, 2011)

Skor Perolehan $=\frac{\text { Jumlahskor }}{\text { SkorMaksimal }} \times 100 \%$

Kriteria kreativitas siswa dari hasil persentase skor perolehan dikategorikan sebagai berikut (Khanafiyah, 2010).

Tabel 3.3 Kriteria Kreativitas Siswa

\begin{tabular}{|c|c|}
\hline Interval Skor rata-rata & Kategori \\
\hline $81,6 \%-100 \%$ & Sangat Kreatif \\
\hline $61,2 \%-81,5 \%$ & Kreatif \\
\hline $40,8 \%-61,1 \%$ & Cukup Kreatif \\
\hline $20,4 \%-40,7 \%$ & Kurang Kreatif \\
\hline $0,00 \%-20,3 \%$ & Tidak Kreatif \\
\hline
\end{tabular}

Menguji efektivitas pembelajaran dengan metode guided discoveryuntuk mengajarkan kemampuan berpikir kreatif digunakan rumus gain ternormalisasi menurut Wiyanto (2008) sebagai berikut:

$$
\langle g\rangle=\frac{\left\langle S_{\text {post }}\right\rangle-\left\langle S_{\text {pre }}\right\rangle}{100 \%-\left\langle S_{\text {pre }}\right\rangle}
$$

Simbol $\left\langle S_{\text {post }}\right\rangle$ dan $\left\langle S_{\text {pre }}\right\rangle$ masing-masing menyatakan skor rata-rata pretest danpostest setiap individu. Besarnya faktor $\mathrm{g}$ dikategorikan sebagai berikut:

Tabel 3.4 Kriteria $\mathrm{N}\langle g\rangle$

\begin{tabular}{|l|l|}
\hline Interval Skor & Kategori \\
\hline $\mathrm{g}>0,70$ & Tinggi \\
\hline $0,30<\mathrm{g}<0,70$ & Sedang \\
\hline $\mathrm{g}<0,30$ & Rendah \\
\hline
\end{tabular}

Indeks sensitivitas merupakan ukuran seberapa baik butir itu membedakan tingkat kemampuan antara siswa sebelum menerima pembelajaran dan sesudah 
menerima pembelajaran. Gronlund (1982) menjelaskan sensitivitas butir soal dihitung dengan rumus sebagai berikut:

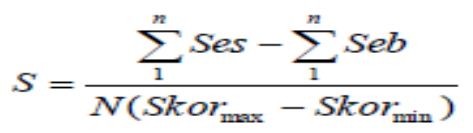

Keterangan:

$S=$ Indeks sensitivitas butir soal

$N=$ Banyaknya siswa yang mengikuti tes awal dan akhir $\sum^{n}$ Ses $=$ Jumlah skor subyek setekah proses pembelajaran $\sum_{\substack{1 \\ n}}$

$\sum_{1}^{n} S e b=$ Jumlah skor subyek sebelum proses pembelajaran Skor $_{\max }=$ Skor maksimal yang dicapai subyek

Skor $\min =$ Skor minimal yang dicapai subyek

\section{c. Analis Respon Siswa}

Lembar respon siswa diberikan setelah kegiatan belajar mengajar dengan memprosentasekan frekuensi jumlah respon dari siswa dibagi dengan seluruh respon dikalikan 100\%. Borick (1994) menjelaskan prosentase respon siswa dihitung dengan menggunakan rumus:

$$
\text { Respon siswa }=\frac{\text { Jumlahsiswamemberiresponaspektertentu }}{\text { Jumlahseluminsiswa }} \times 100 \%
$$

\section{d. Analisis Hambatan Pembelajaran}

Kendala selama pelaksanaan kegiatan belajar mengajar dianalisis dengan deskriptif kualitatif yaitu pengamat dan peneliti memberikan catatan hambatanhambatan yang terjadi pada pelaksanaan pembelajaran sebanyak tiga pertemuan disertai dengan saran dari pengamat.

\section{HASIL PENELITIAN DAN PEMBAHASAN}

\section{A. Hasil Pengembangan Perangkat Pembelajaran}

Hasil pengembangan perangkat pembelajaran fisika model inkuiri terbimbing yang dikembangkan valid untuk digunakan dalam pembelajaran fisika untuk melatihkan kemampuan multi representasi.

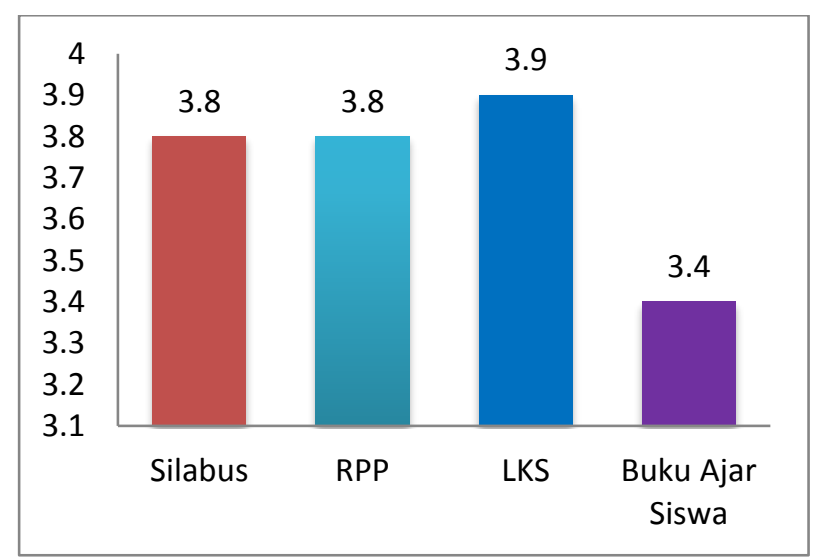

Gambar 1.Hasil validasi pengembangan perangkat pembelajaransains

\section{B. KeterlaksanaanPerangkat Pembelajaran} Keterlaksanaan RPP

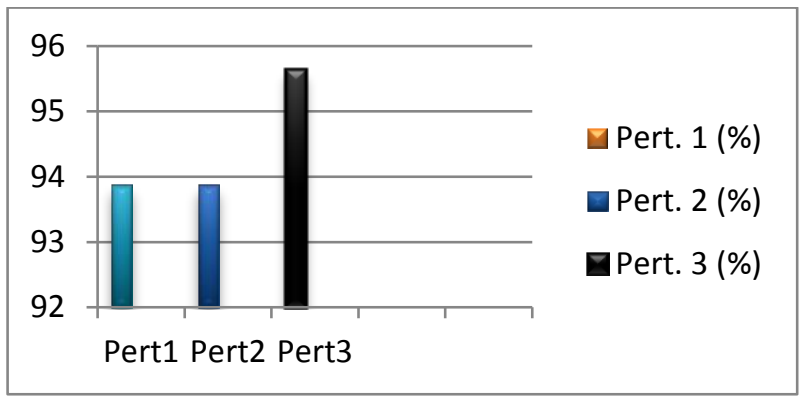

Gambar 2.Keterlaksanaan RPP

Semua tahap-tahap kegiatan yang ada di dalam RPP terlaksana dengan kategori sangat baik.

\section{Hasil Ketuntasan Individu Penguasaan Konsep}

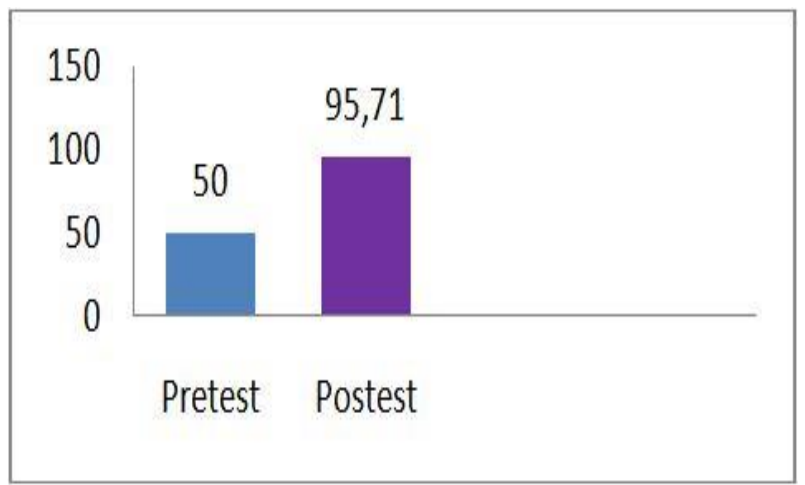

Gambar 3. Rata- rata analisis ketuntasan Individu

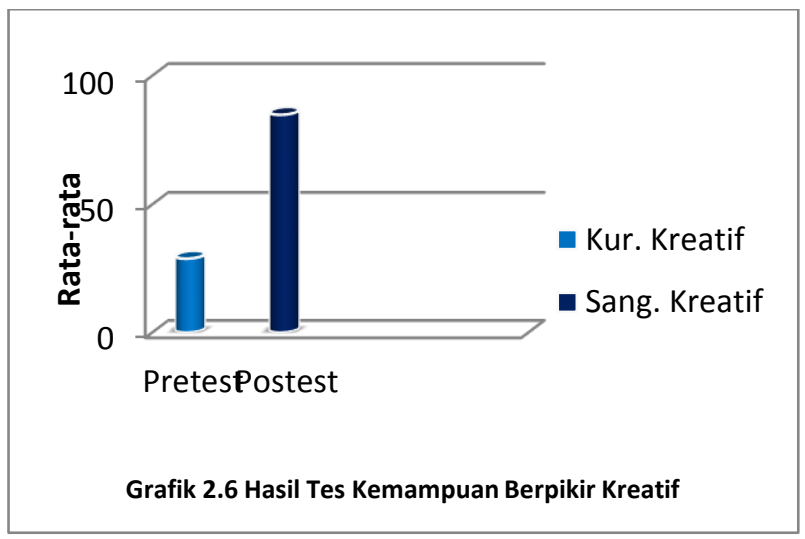

Pada pembelajaran yang berpedoman pada RPP, dapat dilaksanakan dengan sangat baik. Perolehan porsentase keterlaksanaan pembelajaran mencapai nilai $93,87 \%$, artinya aspek kegiatan yang dilakukan sesuai, sistematis, dan tepat dengan sintaks pembelajaran berorientasi guided discovery. Keterlaksanaan ini mendeskripsikan keberhasilan guru dalam menerapkan tahap-tahap dalam pembelajaran. Apabila paparan mengenai keterlaksanaan pembelajaran maka dapat diketahui bahwa dari keempat aspek yang diamati dalam pelaksanaan pembelajaran, yaitu kegiatan awal, kegiatan inti, kegiatan penutup, dan pengamatan suasana kelas, 
secara keseluruhan menunjukkan skor rata-rata hasil pengamatan di atas 3,00 dan berkategori sangat baik. Hasil pembelajaran berorientasi guided discovery ini merupakan hal yang baru baik bagi peneliti maupun siswa.

Analisis data memperlihatkan ketuntasan individu pada uji awal (pretest) digunakan 35 siswa yang mengikuti tes seluruhnya belum tuntas dengan nilai ratarata 50.Hal tersebut disebabkan siswa belum pernah diajarkan materi perubahan lingkungan dan daur ulang limbah. Pada uji akhir (postest) secara individual semua siswa dikategorikan tuntas dengan nilai rata-rata 95,71. Hasil ini membuktikan bahwa PBM dengan menggunakan perangkat pembelajaran berorientasi guided discovery dapat meningkatkan pemahaman konsep siswa sesuai dengan kriteria ketuntasan minimal (KKM) yang ditentukan untuk mata pelajaran biologi di SMA Negeri 1 Manyar mencapai nilai $\geq 75$.

Rata-rata skor pretest berpikir kreatif adalah $28,86 \%$ yang berkategori kurang kreatif. Hal ini dikarenakan, sebagian besar siswa belum bisa mengeluarkan ide yang beragam dan benar dikarenakan materi belum dijelaskan, sehingga siswa banyak yang merasa kesulitan. Rata-rata skor postest berpikir kreatif adalah $84,86 \%$ dengan kategori kreatif. Hal ini dikarenakan siswa sudah mulai bisa mandiri, lancar dalam mengeluarkan ide, mengeluarkan banyak gagasan yang benar, mampu membuat langkah-langkah kerja dalam LKS secara madiri dan mampu mengerjakan tugas dengan baik.

Respon siswa yang terlihat bahwa seluruh siswa selama mengikuti pembelajaran berorientasi guided discovery secara umum menyatakan sangat senang danmenunjukkan bahwa $71 \%$ siswa menyatakan pembelajaranyang berorientasi guided discovery merupakansifat baru bagi siswa, karena memang sebelumnya guru belum pernah menerapkan. Tetapi terdapat $6 \%$ siswa yang menyatakan pembelajaran berorientasi guided discovery ragu-ragu, hal ini dimungkinkan pembelajaran yang diajarkan hampir sama dengan pembelajaran yang didapatkan sebelumnya.

Pembelajaran yang diajarkan membuat siswa mamapu memahami materi menunjukkan $77 \%$ siswa sangat senang. Hal ini sesuai dengan penguasaan konsep yang diajarkan guru pada siswa. Respon siswa sangat senang yang menyatakan dapat mengembembangkan kreativitasnya menunjukkan80\%.Dilihat dari LKS yang dikembangkan menurut siswa modelnya baru sangat senang $77 \%$. LKS yang dikembangkan memudahkan siswa memecahkan masalah respon siswa $80 \%$ sangat senang. Pada LKS yang dipelajari, kegiatannya memberikan kebebasan dalam mengemukakan ide siswa yaitu $77 \%$ Untuk pertanyaan yang diajarkan singkat, mudah, jelas serta mudah dimengerti siswa senang mencapai $71 \%$.

Berdasarkan dari respon siswa tersebut dapat dikatakan bahwa perangkat pembelajaran berorientasi guided discovery mampu mengajarkan kemampuan bepikir kreatif dan penguasaan konsep siswa.

Hambatan yang dihadapi guru berdasarkan masukan dari pengamat dan peneliti menemukan solusi. Hambatan yang diperoleh hanya terletak pada pemahaman siswa dalam mengikuti pembelajaran. Tiap siswa memiliki perbedaan dalam memahami materi, sehingga seringkali waktu yang diberikan untuk suatu permasalahan habis karena ada beberapa siswa yang belum menyelesaikan masalah.

\section{DAFTAR PUSTAKA}

Badan Standar Nasional Pendidikan. 2006. Panduan penyusunan kurikulum tingkat satuan pendidikan jenjang pendidikan dasar dan menengah. Jakarta: BSNP.

Borich, G.D.1994. Observative skill for effective teaching. New York: Mc Millan Publishing Company.

Carin, A.A 1993. Teaching science through discovery. Toronto: Meerll Publishing Company.

Damanhuri, E., Padmi, T. 2010. Pengelolaan sampah. Program Studi Teknik Lingkungan Fakultas Teknik Sipil dan Lingkungan, ITB.

Daryanto. 2009. Panduan proses pembelajaran kreatif dan inovatif.Teori \& praktik dalam pengembangan profesionalisme bagi guru. Jakarta: Publisher.

Daryanto dan Tasrial. 2012. Konsep pembelajaran kreatif. Yogyakarta: Gava Media.

Devi, P.K. 2010.Keterampilan proses dalam pembelajaran IPA. Pusat Pengembangan dan Pemberdayaan Pendidik dan Tenaga Kependidikan Ilmu Pengetahuan Alam (PPPPTK IPA) untuk Program Bermutu.

Dewi, I.N. 2013.Upaya melatihkan keterampilan berpikir kritis mahasiswa melalui pengembangan buku panduan praktikum pengetahuan lingkungan berorientasi guided discovery learning.Program Pascasarjana Program Studi pendidikan Sains.Universitas Negeri Surabaya.

Diamond, I. 2006.Science education in schools. TheAssociation For Science Education.

Direktorat Jendral Pendidikan Menengah Kementerian Pendidikan dan Kebudayaan. 2013. Kumpulan Peraturan Pemerintah dan Peraturan Menteri Pendidikan dan Kebudayaan Republik Indonesia tentang implementasi kurikulum 2013.Jakarta: Depdikbud.

Direktorat Pengairan dan Irigasi Kementerian Perencanaan Pembangunan Nasional/Badan Perencanaan Pembangunan Nasional (Bappenas). 2002. Pengelolaan kualitas air dan pengendalian pencemaran air. Jakarta: Bappenas.

Eggen, P dan Kauchak, D. 2012.Strategi dan Model Pembelajaran Mengajarkan konten dan keterampilan berpikir.Wahono. S. Edisi Keenam. Jakarta Barat: Indeks.

Firmanto, A. 2013."Kecerdasan, Kreatifitas, Task Commitment dan jenis kelamin sebagai prediktor prestasi hasil belajar siswa”. Jurnal Sains dan Praktik Psikologi. Magister Psikologi UMM, ISSN: 2303-2936. Volume I (1), 26 - 36

Gholamian, Ali. 2013. "Studying the effect of guided discovery learning on reinforcing the creative thinking of sixth grade girl students in qom during 2012-2013 academic year".Journal of Applied 
Science and Agriculture, 8(5) October 2013, Pages: 576-58.

Gronlund. 1982. Constructing achievement Tes. Prentice Hall. London

Gronlund, N. E. 1985. Constructing Achievement Test. $5^{\text {th }}$ Edition. New York: Prentice Hall, Inc.

Harini, S. 2011. Pembelajaran kooperatif STAD untuk menumbuhkan kreativitas siswa pada sistem persamaan linier dua variabel.Tesis.Universitas Negeri Malang.

Ibrahim, M. 2008. Model pembelajaran inovatif ipa melalui pemaknaan. Unesa. Surabaya: Tim Balitbang Diknas.

Ibrahim, M. 2010. Dasar-dasar proses belajar mengajar. Surabaya: Unesa University Press.

Jabeen, S \& Khan, M.A. 2013.“A study on creative thinking abilities and self-concept of high and low achievers".Unique Journal of education Research.Vol. 1(1), pp. 001-011, April, 2013 Available online @ http: // www. uniqueresearchjournals.org/UJER @2013. Diakses 22 November 2013.

Jazuli, A. 2009."Berfikir Kreatif dalam kemampuan komunikasi matematika". Seminar Nasional Matematika dan Pendidikan Matematika FMIPA UNY. Program Studi Pendidikan Matematika Universitas Muhammadiyah Purwokerto. Diakses 10 Februari 2014.

Kesumawati. N. 2008. Pemahaman konsep matematik dalam pembelajaran matematika.FKIP Program Studi Pendidikan Matematika Universitas PGRIPalembang.http://eprints.uny.ac.id/6928/1/P18 \%20Pendidikan(Nila\%20K).Di akses 12 Maret 2014.

Khanafiyah, S dan Rusilowati, A.2010. Penerapan pendekatan modified free inquiry sebagai upaya meningkatkan kreativitas mahasiswa calon guru dalam mengembangkan jeensi eksperimen dan pemahaman terhadap materi fisika. Jurnal Pendidikan FMIPA. Universitas Negeri Semarang

Khasnis, B.Y \& Aithal, M. 2011.Guided discovery method a remedial measure in mathematics.Research paper physiology.international referred research journal, July, 2011,ISSN-0975-3486,RNI: RAJBIL 2009/30097,VOL-II.ISSUE 22. Diakses 19 September 2013.

Lavine, R.A. 2005. Guided Discovery learning with videotaped case presentation in neurobiology.Department of Pharmacology \& Physiology The George Washington University

Lasem Kabupaten Rembang.Institut Agama Islam Negeri (IAIN) Walisongo Semarang.

Semiawan, C.R. 2010. Kreativitas keberkatan: mengapa, apa, dan bagaimana.Jakarta: Indeks.

Siswono, T.Y.K. 2007.Desain tugas untuk mengidentifikasi kemampuan berpikir kreatif siswa dalam matematika.Diakses 10 februari 2014.

Siswono, T.Y.K dan Novitasari, W. 2009.Meningkatkan kemampuan berpikir kreatif siswa melalui pemecahan masalah tipe what's another way. Jurusan Matematika FMIPA Universitas Negeri Surabaya.Diakses 10 Februari 2014.
School of Medicine and Health Sciences Washington, DC 20037 U.S.A. Diakses 12 Desember 2013.

Markaban. 2006. Model pembelajaran matematika dengan pendekatan penemuan terbimbing. Pusat pengembangan dan Penataran Guru Matematika. Yogyakarta: Departemen Pendidikan Nasional.

Melani, R., Harlita., Sugiharto, B. 2012. Pengaruh metode guided discovery learning terhadap sikap ilmiah dan hasil belajar kognitif biologi siswa SMA Negeri 7 Surakarta Tahun Pelajaran 2011/2012. Hal: 97-105. Diakses 6 April 2013.

Munandar, U. 1999. Kreativitas dan keberkatan.Jakarta: Gramedia Pustaka Utama.

Munandar, U. 2009. Pengembangan kreativitas anak berbakat.Jakarta: RinekaCipta.

Nur, M. 2008. Pengajaran berpusat pada siswa dan pendekatan konstruktivis dalam pengajaran edisi kelima.Universitas Negeri Surabaya. PSMS.

Qorri'ah, 2011.Penggunaan metode guided discovery learning untuk meningkatkan pemahaman konsep siswa pokok bahasan bangun ruang sisi lengkungan.Jurusan Pendidikan Matematika Fakultas Ilmu Tarbiyah dan Keguruan.UIN Syarif Hidayatullah. Jakarta: 2011.

Ratumanan.T.G, Laurens. T. 2011. Penilaian Hasil Belajar Pada Tingkat Satuan Pendidikan. Edisi2.Unesa University Press.

Risnanosanti, 2009. Penggunaan pembelajaran inkuiri dalam mengembangkan kemampuan berpikir kreatif siswa sma di kota bengkulu. Program studi pendidikan matematika universitas muhammadiyah Bengkulu.

http://eprints.uny.ac.id/7045/1/P30\%20Risnanosanti. Diakses 25 Desember 2013.

Rohim, F., Hadi, S., Ellianawati. 2012. "Penerapan model guided discovery pada pembelajaran fisika untuk meningkatkan kemampuan berpikir kreatif". Unnes Physics Education Journal.http://journal.unnes.ac.id/sju/index.php/upej. Diakses 23 September 2013.

Sagala, S. 2003. Konsep dan makna pembelajaran untuk membantu memecahkan problematika belajar dan mengajar.Bandung: Alfabeta.

Sanjaya, W. 2006.Strategi pembelajaran berorientasi standar proses pendidikan. Jakarta: Prenada Media Group.

Saputro, H.E. 2012. Implementasi metode guided discocery dalam pembelajaran PAI di SMP negeri 1

Siswono, T.Y.K \& Budayasa,I. 2006. Implementasi teori tentang tingkat berpikir kreatif dalam matematika.Jurusan Pendidikan Matematika FMIPA UNESA. Diakses 24 November 2013.

Sugiyono. 2012. Metode penelitian pendidikan pendekatan kuantitatif, kualitatif, dan $R \& D$. Bandung: Alfabeta.

Suprijono, A. 2009.Cooperative learning.Teori dan Aplikasi PAIKEM. Yogyakarta: Pustaka Pelajar.

Udo., Effiong, M. 2010. "Effect of guideddiscovery student centred demonstration and the expository instructional strategies on students performance in chemistry". African research Review.An 
International Multi-Disciplinary Journal.Department of Science Education, University of Uyo, Uyo Cross River State, Nigeria.Vol. 4 (4), Serial No. 16, October, 2010(Pp. 389-398).

Undang-undang Republik Indonesia Nomor 32 Tahun 2009. Tentang Perlindungan Dan Pengelolaan Lingkungan Hidup. Jakarta.

Wardhana, W.A. 1995. Dampak pencemaran lingkungan. Jakarta: Andi Offset.

Wardani, S. 2008. Pengembangan keterampilan proses sains dalam pembelajaran kromatografi lapis tipis melalui praktikum skala mikro. urusan Kimia FMIPA Universitas Negeri Semarang.JurnalInovasi Pendidikan Kimia. Vol.2, No.2, 2008, hlm 317-322. Diakses 23 September 2013.

Widhiyantoro, T., Indrowati, M., Probosari, R.M. 2012."The effectiveness of guided discovery method application toward creative thinking skill at the tenth grade students of" SMAN 1 Teras Boyolali in the Academic Year 2011/2012.The Effectiveness of Guided Discovery Method.Pendidikan Biologi.Volume 4, Nomor 3 September 2012 Halaman 89-99. Diakses 15 November 2013.

Widjajanti, E. 2009.Penanganan limbah laboratorium kimia. Jurusan Pendidikan Kimia FMIPA UNY.

Wiyanto, 2008.Menyiapkan guru sains mengembangkan kompetensi laboraturium. Semarang: Universitas Negeri Semarang Press

Wolfinger. 1984. "A handbook for program development, implementation and evaluation. Ohio Department of Natural Resources, Division of Soil and Water Conservation, 2003".Explanation of teaching continuum.http://wateroutreach.uwex.edu/education/ documents/ExplanationofTeachigContinuum. Diakses 6 Desember 2012. 